\title{
Curbing Dependence on Coal in China and India to Attain Global Carbon Neutrality: Challenges and Options
}

\author{
Bernard Arogyaswamy ${ }^{1}$ \& Waldemar Koziol ${ }^{2}$ \\ ${ }^{1}$ Madden School of Business, Le Moyne College, Syracuse, USA \\ ${ }^{2}$ Faculty of Management, University of Warsaw, Warsaw, Poland \\ Correspondence: Bernard Arogyaswamy, Madden School of Business, Le Moyne College, Syracuse, NY 13214, \\ USA. Tel: 315-445-4727. E-mail: arogyas@lemoyne.edu
}

\author{
Received: January 2, 2022 \\ Accepted: February 6, 2022 \\ Online Published: February 8, 2022 \\ doi:10.5539/ep.v11n1p1 \\ URL: https://doi.org/10.5539/ep.v11n1p1
}

\begin{abstract}
While many developed countries have announced policies for energy transitions, particularly in regard to greenhouse gas emissions, some emerging nations do not appear to be positioned to achieve the goal of net zero carbon. This policy paper focuses on two countries, China and India, which derive the bulk of their energy from coal, and are key to a net zero carbon world. Both countries have prioritized energy security and view all climate initiatives through this prism. They also distinguish between the early industrializers responsible for the bulk of the stock of GHGs, and emerging nations accountable for part of the current flow of emissions. Numerous initiatives have already been undertaken, and policies announced, for cutting carbon emissions in both China and India. However, both countries face major impediments to undertake the measures needed to curb their dependence on coal. Employing a qualitative interpretive methodology rooted in grounded theory, the paper examines the complex energy dynamics facing these two nations, the actions adopted, and policies formulated to limit emissions. The technological, social, political, and financial challenges they face are developed in some detail. Unless mechanisms are devised to support appropriate climate policies, and reduce coal-dependency in China and India, the successful implementation of climate policies in developed nations will not be sufficient to achieve a carbon neutral world.
\end{abstract}

Keywords: coal energy China, coal energy India, energy security, energy social factors, political issues in China \& India, renewables China \& India

\section{Introduction}

As wildfires, floods, droughts, hurricanes, ocean level rising, loss of biodiversity, and other such phenomena intensify, a heightened sense of urgency to deal with the climate crisis/emergency (NASA, 2020; Wallace-Wells, 2019) seems to have taken hold across the world. Reports by respected institutions have made it clear that the window for decisive action is narrow, and rapidly closing (IPCC, 2021; UNEP, 2021). Many of the major carbon emitting nations have set a target date of 2050 (in the case of China, 2060) to reach net zero carbon, that is, emissions minus removals. The EU as a whole aims to reach net zero carbon by 2050 , while cutting emissions by 55\% (from 2005 levels), by 2030 (Europa(a), 2020). The US, after an earlier decision to withdraw from the Paris Accord, appears to be ready to go beyond its obligations by cutting emissions by more than it had committed to by 2030 and achieve a transition to net zero carbon also by 2050 (Darby \& Gerretsen, 2019). Though, the EU and the US are critical to rapidly minimizing carbon emissions, their efforts alone will not succeed in stopping the rise in average global temperatures.

\section{Carbon Emissions from the Energy Sector Are Rising in China and India}

The EU has set in motion policies (Green Deal, Fit for 55), and the United States has proposed a Build Back Better plan, to reach the net zero carbon (GHGs emitted minus GHGs removed) target through a combination of government investments in $\mathrm{R} \& \mathrm{D}$, subsidies and incentives for technologies to decarbonize energy sources (including storage of electricity and grid stabilization), carbon taxes and import tariffs, and so on (Europa, 2020(a); Energy, 2021). Even if the EU and the US manage to make the investments needed and overcome the looming technological challenges that lie ahead, it is critical that other major emitters, particularly China and India, follow through on their commitments to bring global temperature increases under control. 
In this policy-oriented paper, we lay out the plans that each of these Asian countries has formulated to get to a net zero carbon position over the next three to four decades, as well as the multiple challenges that need to be overcome in achieving carbon neutrality. The paper draws extensively on scholarship from a variety of disciplines. The methodology employed subscribes broadly to traditional grounded theory as explicated by Glaser (1992), and refined further by Birks and Mills (2015). Numerous studies employing primary and secondary data, and theoretical formulations by experts in the field, form the bases for identifying the elements underlying, and the direction of, the climate policies being pursued in China and India. The richness of the qualitative-interpretive approach (Hoffmann, 1995) helps explicate the seriousness of the problem faced by both nations in reaching net zero carbon.

While many of the challenges they need to confront might be amenable to technological solutions, the unintended (though foreseeable) consequences of technology-based fixes could slow down progress. In addition, the role played by the political, economic, and social factors which characterize these two nations in determining the outcomes of the plans and policies formulated to help achieve progressive decarbonization are evaluated in the paper (Wang \& Zhou, 2020; Steiner, 2020; Russell, 2019). Possible approaches to deal with the hurdles that China and India and, by extension, the world as a whole, need to surmount, are also addressed. Since coal is used by both countries to meet over half their energy needs (and around 70\% of the electricity generated), much of the focus of the paper will be on reducing dependence on coal as the source of energy for diverse applications.

\section{Energy from Coal in China and India}

China, by far the biggest source of emissions from coal, and India could together add as much or more carbon than the EU and the US combined plan to eliminate by 2035 . China alone presently accounts for around $25 \%$ while the US and EU together account for $20 \%$ of worldwide energy-related emissions. India's share is only around $7 \%$ but that could rise sharply by 2035 if the country's energy demands increase as anticipated. (IEA, 2021).

Fig. 1 illustrates the actual growth in demand in the major energy consuming countries/regions, along with projections up to 2040 (EIA, 2018).

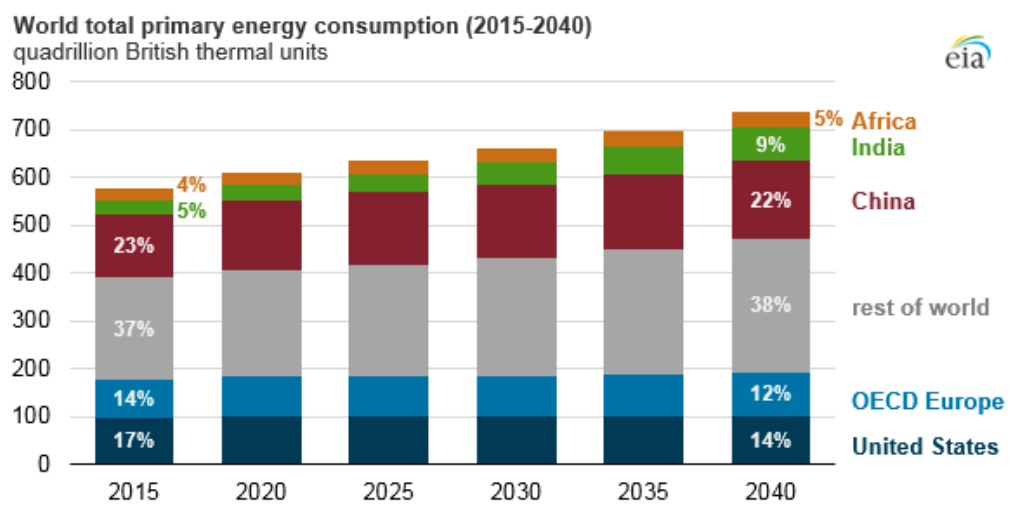

Figure 1. Energy demand in major consuming countries/regions

Source: EIA. 2018. https://www.eia.gov/todayinenergy/detail.php?id=36732

China and India combined could account for about one third of energy consumed and $40 \%$ of emissions in fifteen years. Both countries are heavily dependent on coal for energy, China deriving over $65 \%$ and India more than $70 \%$ of energy from coal (IEA, 2020). During the decade 2009-2019 China and India significantly increased their emissions respectively by $31.1 \%$ and $37.4 \%$, though the demand for coal plateaued in 2011 in the case of China, in part due to rising energy efficiency (Wang \& Zhou, 2020). Additionally, both countries currently plan to develop new coal-based power projects totaling almost 250GW (Carbon Tracker, 2021). Across India, 281 coal plants are operating and beyond the 28 being built another 23 are in pre-construction phases (Varadhan \&Sheldrick, 2021). Simultaneously, China and India are home to almost half the over 2,600 coal-fired plants operating or under construction around the world, and China and India were responsible for about $54.3 \%$ and $11.6 \%$ respectively of global coal consumption in 2020 (Garside, 2021).

The projected demand for coal in millions of tons in the next few years is shown in Table 1. It may be noted that in developed countries, coal use is expected to hold steady or decline, while in less developed nations, with the exception of China, demand for coal was expected to rise. China's coal dependence was expected to decline sharply, 
but as Table 1 shows, in reality, it is projected to only slow marginally in the next few years. The relative stability of China's dependence on coal as an energy source matters immensely since the country uses about as much coal as the rest of the world combined. It is clear that China, India, and the rest of Asia are seeing a slight upward trend in coal-based energy.

Table 1. Actual and projected coal usage in millions of tons

\begin{tabular}{llll}
\hline Year & 2000 & 2017 & 2023 \\
\hline US & 762.7742857 & 472.0171429 & 413 \\
Europe (EU28) & 450.9042857 & 323.2628571 & 280 \\
Japan \& Korea & 198.1014286 & 293.2314286 & 284 \\
China & 954.9328571 & 2752.49 & 2673 \\
India & 208.4628571 & 562.88 & 708 \\
Southeast Asia & 45.49142857 & 186.3328571 & 259 \\
\hline
\end{tabular}

Source: https://www.weforum.org/agenda/2021/01/coal-demand-asia-decarbonize-emissions/

China's CO2 emissions rose by about 30\% in the period 2009-2019 as seen in Table 2. Most of the increase in coal use occurred between 2009 and 2014. India's emissions have also risen sharply during the ten year span.

Table 2. CO2 yearly emissions by selected countries in 2009 and 2019 (in Million metric tons)

\begin{tabular}{lllll}
\hline Country & 2009 & 2019 & 2009-2019 change in mn tons & World rank in 2019 \\
\hline China (Mainland) & $\mathbf{7 , 7 5 9}$ & $\mathbf{1 0 , 1 7 5}$ & (+) 2,416 & $\mathbf{1}$ \\
United States & 5,491 & 5,285 & $(-) 206$ & 2 \\
India & $\mathbf{1 , 6 1 3}$ & $\mathbf{2 , 2 1 6}$ & $\mathbf{( + )} \mathbf{6 0 3}$ & $\mathbf{3}$ \\
Russia & 1,529 & 1,678 & $(+) 149$ & 4 \\
Japan & 1,163 & 1,107 & $(-) 56$ & 5 \\
Iran & 547 & 780 & $(+) 233$ & 6 \\
Germany & 790 & 702 & $(-)) 88$ & 7 \\
Indonesia & 447 & 618 & $(+) 171$ & 8 \\
South Korea & 507 & 611 & (+) 104 & 9 \\
Saudi Arabia & 466 & 582 & (+) 116 & 10 \\
\hline
\end{tabular}

Source: https://www4.unfccc.int/sites/submissions/indc/Submission\%20Pages/submissions.aspx

There was a slight decline in emissions in 2020 resulting from less economic activity due to the pandemic (World Population Review, 2021), but emissions have started rising again. In fact, pent-up demand may fuel a spike in emissions to more than compensate for the drop during 2020. The COVID-19 pandemic led to an unprecedented 5.4 per cent drop in global carbon dioxide (CO2) emissions in 2020. According to UNEP (2021) a strong rebound in emissions is expected in 2021. Preliminary estimates suggest $\mathrm{CO} 2$ emissions could grow by 4.8 per cent in 2021 (excluding cement), and global emissions in 2021 are expected to be only slightly lower than the record level of 2019 (UNEP, 2021). GHG emissions in Europe in the second quarter of 2021 increased by $18 \%$ compared with the same quarter in the previous year. This is largely due to the effect of the economic rebound after the sharp decrease of activity in the same quarter of 2020 due to the COVID-19 crisis (Europa, 2021(a)).

\section{Energy Security: Vital to National Security}

For large countries such as China and India, rapid economic growth offers a pathway to solve significant social 
problems such as lack of meaningful employment, poverty and hunger, rural populations without electricity, unreliable energy sources, and so on. The desire for energy security is paramount in both nations and their expressed determination to address climate change should, at least in part, be viewed from this perspective (Wu, 2018). Energy security entails ensuring reliability of energy supply in the quantity needed, at an affordable price. (Yergin, 2020) Energy is vital to national wellbeing and political stability. Energy and national security are inextricably linked and Chinese and Indian leaders have made this abundantly clear (Hari, 2019; Wu, 2018).

Both countries' dependence on imported petroleum as well as on LNG for transportation and industrial use illustrates the intimate connection between energy security and national interests. Not only are supply lines long, they often originate in locations subject to unrest and conflict, and traverse sea lanes which are subject to interdiction by potentially hostile nations. Prices are liable to fluctuate, high prices creating obvious problems for users, while low prices may result in instability in supplier countries (Wu, 2018). China imports about $75 \%$ of its crude oil needs and about $10 \%$ of the LNG used, the latter expected to grow rapidly by 2030 . India imports about $80 \%$ of crude oil used and over $50 \%$ of its LNG needs (EIA, 2020). As the use of LPG grows in India, its imports are rising as well. Both countries are trying to diversify their suppliers for oil and gas, even looking at USsanctioned nations to minimize over-reliance on a few suppliers (Hong, C., 2012). China's "String of Pearls" i.e. a chain of ports it has helped finance on the Indian Ocean to ensure continuity of supplies, and its attempts to patrol the sea lanes to its shores, shows how vital energy security is to China's development (Hughes, 2019). This has aroused concern in Washington, Delhi, Tokyo, and other capitals over the geopolitical reach of the Chinese Navy. India has undertaken countermeasures to safeguard its interests, and is actively engaged in ensuring its access to these fossil fuels albeit its supply lines are shorter than China's (Edens, 2018)

With approximately $30 \%$ of their energy supply subject to forces outside their borders and control, it is unlikely that either China or India will take action to shift away from coal mined within their territories unless they are certain that its replacement is reliable, affordable, and available in sufficient amounts. In fact, at COP 26, at the insistence of China and India, the latter in particular, the draft proposal to "phase out" coal was modified to "phase down" (Yin, 2021). India's Environment and Climate Minister argued that the remaining carbon budget should be allotted to developing countries to enable them to make progress on their economic agendas and eradicate poverty (Reuters, 2021).

Both nations' leaders and policy makers recognize that it is in their respective national interests to minimize net emissions in the long run to improve air quality, reduce the incidence and intensity of extreme weather events, support the poor and marginalized, and give future generations a better life. The pull exerted by energy security and economic growth should not, however, be underestimated. In this connection, it is worth noting that the dilemma of ensuring reliable energy supplies while minimizing their environmental impact is not unique to China and India. The U.S. has vastly expanded its domestic access to oil and natural gas in large part to guarantee availability of vital energy resources. Germany and Japan have forsworn the use of nuclear power for electricity, but have had to fall back on coal, even if temporarily, to ensure reliable energy supplies. The German coalition government installed in 2021 envisages an acceleration of coal phase out to 2030 from 2038. The EU as a whole, as it transitions to net zero carbon, also faces a similar tradeoff involving, among other factors, greater reliance on renewables, the use of natural gas, and dealing with geopolitical rivalries (Morningstar, 2020). Though the bloc needs to import oil and gas, it might be better placed than China and India to manage its energy future, while lowering carbon emissions.

It is in the interest of industrialized nations which have successfully followed a path to low carbon emissions to work with countries such as China and India to facilitate their progress toward net zero carbon without jeopardizing economic outcomes, and ensuring energy security. Gatherings such as the COPs, should not become forums to pressure China, India, and other developing countries to conform to developed nations' climate goals but to help each country find its optimal path to reach net zero carbon, while providing the necessary financing and other support to overcome country-specific challenges. According to the Paris Agreement, $\$ 100$ billion was to be disbursed to developing countries, to be divided equally between mitigation and adaptation. The amounts transferred so far have fallen short of that target, reaching $\$ 80$ billion in 2018, the bulk of which was in the form of loans, and focused on mitigation which would yield a measurable return on investment (Timperley, 2021; Shankleman, 2020). The actual needs of developing countries are many multiples of the amount promised excluding the compensation for "loss and damage", consideration of which has been postponed to a later date.

\section{Emission Commitments}

During global climate Conference of Parties (COPs) dating back to 1995, the importance of emission reduction has been acknowledged. At COP 21 held in Paris in 2015, over 190 countries adopted emission reduction targets 
which constituted their Nationally Determined Contributions (NDCs). The emission reductions proposed by major economies by 2030 are shown in Table 3, with many nations aiming for large declines in emission by 2030 .

Table 3. Post 2020 country CO2 emission targets

\begin{tabular}{|c|c|c|}
\hline Country/region & Stated target & Change from 2005 in 2030 \\
\hline UK & 50 per cent below 1990 levels by 2023-2027 & -61 per cent \\
\hline Germany & 55 per cent below 1990 by 2030 & -45 per cent \\
\hline US & 26 to 28 per cent below 2005 by 2025 & -35 to -39 per cent \\
\hline $\mathrm{EU}$ & At least 40 per cent below 1990 by 2030 & -34 per cent \\
\hline Canada & 30 per cent below 2005 levels by 2030 & -30 per cent \\
\hline Australia & 26 to 28 per cent below 2005 levels by 2030 & -26 to -28 per cent \\
\hline Japan & 26 per cent below 2013 levels by 2030 & -25 per cent \\
\hline China & $\begin{array}{l}\text { Peak CO2 emissions around 2030; 60-65 per cent } \\
\text { reduction in carbon intensity by } 2030 \text { on } 2005 \text { level }\end{array}$ & +72 to +96 per cent \\
\hline Republic of Korea & 37 per cent below BAU by 2030 & +1 to -5 per cent \\
\hline India & $\begin{array}{l}\text { Reducing the emissions intensity of its GDP by } 20 \\
25 \% \text {, over } 2005 \text { levels, by } 2020\end{array}$ & n.a. \\
\hline
\end{tabular}

Source: https:/www.statista.com/statistics/270499/co2-emissions-in-selected-countries/

China has indicated it will reach peak carbon in 2030 without, however, specifying what the peak would be. An informal undertaking has been given that the country would reach carbon neutrality around 2060, though details are awaited on how this would be accomplished. India's commitments are also incompatible with becoming carbon-free anytime in the next few decades. The NDCs proposed by India in the Paris Agreement, which are the current targets, are relatively easily realized, and do not constitute a substantial reduction in carbon dependence (Mohan \& Wehnert, 2019). In fact, for both countries, the outcome, by 2030, is likely to be a significant increase in $\mathrm{CO} 2$ emissions, since expected GDP growth outstrips the decline in emission intensity (CO2 per unit of GDP).

It is critical to note that if the absolute emissions of the Chinese and Indian economies are not reduced as a result of lowering emission intensity, the effectiveness of their climate policies, and the world's ability to limit the temperature rise to $1.5^{\circ} \mathrm{C}$ or even $2^{\circ} \mathrm{C}$ could be seriously jeopardized (Climate Action Tracker, 2021 (a); Climate Action Tracker, 2021 (b)).

The authors sketch out in the following sections the extent of dependence of both economies on coal, why replacing coal is such an uphill task, and what needs to be done to reduce dependence on this source of energy.

\section{Coal Use}

\subsection{China}

China's policy makers project that the country's use of coal will peak in 2030 and decline thereafter. However, in the electricity sector, which accounts for the bulk of coal burning, capacity which was to be capped at 1100GW, had reached nearly $1200 \mathrm{GW}$ in 2020 , with over $240 \mathrm{GW}$ of planned additions (Standway, 2021). Since coal fired plants have lives of around thirty years, and many older stations are also being upgraded, China appears to be locking in massive amounts of coal use for power till 2050 and beyond (Standaert, 2021). Climate Action Tracker (2018) rates China's energy policies to be incompatible with a $2^{\circ} \mathrm{C}$ scenario, and more in keeping with a $4^{0} \mathrm{C}$ temperature increase.

In addition to electricity generation, coal is heavily used in the manufacture of steel, cement and aluminum whose carbon output is locked in at about $25 \%$ of China's total emissions, with steel production alone accounting for $30 \%$ of the coal used (Myllyvirta, 2021).

Petroleum contributes about $20 \%$ of $\mathrm{CO}_{2}$, and seems to be an area in which China's plans to electrify vehicles and install charging stations appear likely to bear fruit by 2030. The ramp up in electric vehicle (EV) sales is clearly a big step toward curbing the use of liquid fossil fuels. However, with coal being such a big part of China's energy mix, EV charging stations are likely to be dependent on coal-based power, which would result in a net addition to 
carbon emissions.

Reduced reliance on fossil fuels in a country whose emissions are already high, and which aims to grow at or near double digit rates over the coming decades, is a monumental task. Getting regional buy-in, grid stabilization and capacity expansion, and urgently needed radical technological advances in manufacturing processes, hydrogen production and storage, etc., and shifting the economy to a services orientation, are some of the factors which could facilitate achieving net zero carbon in three or four decades.

\subsection{India}

India's population is almost as large as that of China, but economically its size in terms of GDP is about one-fourth that of its Asian neighbor. Its carbon emissions, at around 2.2 gigatonnes, are a little over one-fifth China's and around $40 \%$ of US emissions (Timperley, 2019). Per capita, India's carbon emissions at 1.8 tons (Our World in Data, 2020) are relatively miniscule in comparison to the U.S. (16 tons) and the E.U. and China (both around 7.5 tons). However, it is worth noting that, in the decade ending 2019, the country's CO2 output rose by nearly $40 \%$. With plans to grow the economy rapidly in the coming decades, India's emissions look set to rise by over $50 \%$ from present levels by 2030, even with the expansion of its ongoing commitment to rapidly grow renewable energy capacities (Climate Action Tracker, 2020). Coal continues to provide over $70 \%$ of the electricity consumed. Despite the rise in emissions, Climate Action Tracker (2018) had viewed India's energy usage trend to be consonant with a $2^{\circ} \mathrm{C}$ rise outlook. Subsequently, the same publication has downgraded India's efforts as 'highly insufficient', the same category as has been assigned to China (Climate Action Tracker, 2021).

India's rapid scaling up of renewable capacity, primarily wind and solar, which have seen double digit growth every year for the past five years has been impressive (Nature, 2020). India's embrace of renewables has been partly driven by their effectiveness in bringing electric power to hitherto unserved rural areas, as well as the cost of electricity from some new solar plants being lower than coal-based electricity. Nevertheless, as we discus later in the paper, coal's dominance as an energy source endures.

\section{Renewable Energy}

\subsection{China}

Renewable capacity has, to be sure, increased in leaps and bounds reaching a total of $281 \mathrm{GW}$ in wind power and $253 \mathrm{GW}$ in solar, more than installed capacity in the rest of the world combined. (Xu and Stanway, 2021). However, even with recent additions to renewable capacity, the impact of wind and solar is somewhat attenuated by the relatively low load factor of $16 \%$ for wind (compared to $32 \%$ in the US and $22 \%$ in the EU) and about $15 \%$ for solar (Chatsko, 2018). Among the reasons for the low capacity utilization specific to China are the fact that renewable plants are mainly located in the north, far from demand centers, the lack of storage capacity for intermittent wind and solar generation, a grid which is incapable of handling the swings in renewable energy generation, and the desire on the part of some local authorities to continue the use of coal power generated within their respective regions (Physics World, 2018).

\subsection{India}

Renewable energy installations have had a limited impact on India's carbon emissions due to some of the same reasons that have caused China's renewable energy usage (as opposed to capacity available) to falter: intermittency and electricity storage issues, local resistance, strength of the coal lobby, and the grid's inability to handle frequent variations in power availability (IEA, 2021). Other hurdles to expanding renewable capacity include the imposition of tariffs on imported solar panels, the bulk of which are from China, and frequent delays in payments to distribution companies, which disincentivizes both new and existing renewable energy producers (Lu, Sherman, Chen, Chen, Lu, \& McElroy, 2020). Though the cost of solar power in certain locations is almost on par with coalderived electricity (IEA, 2021), the shuttering of coal-fired plants has not proceeded as expected. In fact, nearly $60 \mathrm{GW}$ capacity of coal power stations are in the pipeline, which suggests that achieving net zero carbon by 2050 is an uphill task unless renewable capacity and reliability are ramped up considerably (IEEFA, 2022).

India's hydro capacity meets about $10 \%$ of its needs, while nuclear generation plays a relatively insignificant role (7GW existing and $8 \mathrm{GW}$ planned additions. Consequently, India's dependence on coal to meet its base load electricity needs seems likely to continue until renewables can pick up the slack. (Vaidyanathan, 2021)

\section{Coal versus Renewables}

The relative costs of using coal and renewables vary across the world including. However, recent data confirms that renewables are already competitive with coal power in China and India. Though it is already cheaper to build new renewable power sources than coal fired plants, new coal investments in both countries continue. Even the 
Long Run Marginal Cost (LRMC) of coal-power is greater than the Levelized Cost of Electricity (LCOE) of renewables for over $60 \%$ of the coal fleets. Of course, the LCOE of renewables requires an immediate fixed investment, which developing countries might not be able to afford, and these sources are subject to fluctuations in power output. It should be noted, however, that the LRMC of coal does not include the adverse health effects of the $\mathrm{CO}_{2}$ emissions associated with it. Also, the continued use of coal for electricity does not disrupt the status quo, enabling the continued use of a fuel whose worth as a stable source of power has been proven

In general, energy investment decisions are not strictly economic in nature, but take into account other factors such as security, political stability, employment, and so on. These factors interact and play out in policy making in complex, even unpredictable, ways.

\section{Carbon Emissions: Stocks and Flows}

Industrialized nations, which are charting a path to lower carbon emissions, need to engage with policy makers and leaders in countries such as China and India to facilitate their progress toward net zero carbon without jeopardizing economic outcomes, while ensuring energy security. Gatherings such as the COPs, should not become forums aimed solely at pressuring China, India, and other developing countries to conform to developed nations' climate goals. This approach invites a response from developing nations that developed countries, responsible for the bulk of the carbon emissions over the past two centuries need to scale back their emissions drastically. while providing the necessary financing and other support to overcome country-specific challenges. Finding constructive ways to facilitate the energy transition and providing the financial wherewithal to do so as committed, would be an effective way to move developing nations toward decarbonization.

Having contributed, over the past century and a half, to over 50 percent of the carbon dioxide (CO2) stock in the atmosphere (Richie, 2019), Europe and North America, will need to do more to get to a net carbon zero world. Having consumed the bulk of the planet's "carbon budget" the two leading industrialized regions need to consider doing more than reaching net zero carbon at home. Financial support, technology transfer, and other such means, need to be deployed to bolster the efforts of developing nations to reduce emissions. In addition, developed countries could intensify research in carbon capture and sequestration as well as natural approaches to carbon absorption such as through preserving and adding to forests, wetlands and other such carbon reduction mechanisms while minimizing reliance on offsets (Brookings, 2021).

Like many other developing nations, China and India have followed the fossil fuel driven growth model adopted by the industrialized West, while seeking to maximize GDP growth. Though energy efficiency has also risen in both Asian countries, it has lagged GDP growth, resulting in higher overall emission levels.

Additionally, the sharp increase in manufacturing outsourcing has led to the offshoring of emissions especially over the past three decades, sometimes to the tune of three million tons (MT) a year, though it has now declined to less than 2 MT per year on average (Plumer, 2017). Post-pandemic, this is likely to rise again along with carbon attributable to freight which is responsible for about $5 \%$ of total emissions, and could grow sharply by 2050 (OECD, 2015). The imposition of a carbon tariff on imports from countries whose policies to decarbonize are deemed insufficient has been proposed (Europa, 2021), but needs to be debated more widely. Such a "border adjustment mechanism" would penalize the flow of emissions while those most responsible for the stock of emissions (and much of the $1^{0} \mathrm{C}$ rise over pre-industrial levels) face no such impost.

\section{Development and Implementation of New Technologies}

If the US and the EU succeed in their mitigation efforts and slash emissions by $50 \%$ or more by 2035 , it is quite probable that China and India will together be generating nearly half of the world's GHGs by that date (EIA, 2018). Total worldwide emissions may decline somewhat from the current level of 50 gigatons $\mathrm{CO} 2 \mathrm{e}$, but the world might pass the $2^{0} \mathrm{C}$ mark by then or soon after, unless transformative developments in technology occur, accompanied by the political and social will to implement them.

In order for China and India to drastically reduce their dependence on coal, alternative carbon-free sources of energy must become reliably available in large quantities. One of the primary hurdles to be overcome is the inability to store electricity at grid scale to meet base load demand. Whether in the form of pumped storage, batteries, hydrogen, or some other method, the development of these technologies is by no means assured of success in the near term, particularly at the scale needed to substitute renewables for coal. Though a slew of startups is seeking to address this need, the challenge is to store energy for hours, even days, when solar and wind power are idle (Temple, 2019). Problems concerning material availability and extraction also need to be confronted. Lithium, cobalt, rare earths, and other materials needed for batteries are found in limited geographic areas, and entail addressing local ecological and social issues. Similar challenges need to be overcome in regard to materials 
needed for solar panels, wind turbines, hydrogen production and storage, and so on (Kramarz. Park, \&Johnson, 2020; Sovacool, 2021). In light of the likelihood of carbon emissions remaining at significant levels beyond 2030, methods to capture carbon at the point of emission or directly from the atmosphere may become critical to achieving net zero carbon. These technologies are at a nascent stage, and are still years from being commercially viable, but may be crucial to countries like China and India adhering to their carbon limit commitments. Equally important carbon absorption and capture technologies are critical to Europe and North America if they wish to demonstrate the willingness to act to compensate for the bulk of GHG stock attributable to them, while also addressing the ongoing flows. Direct Air Capture (DAC) of $\mathrm{CO}_{2}$ of the order of 10 billion tons would be needed by 2050 to achieve carbon neutrality (Clancy, 2021). It is estimated that the DAC industry would then match the current size of the fossil fuel industry. The gradual convergence of startups, venture capital, university research, and government funding makes this a promising industry, though even capturing a few hundred million tons of $\mathrm{CO}_{2}$ by 2030 seems an ambitious target. The cost of DAC today is daunting. Lebling, McQueen, Pisciotta, $\&$ Wilcox (2021) estimate that it ranges between $\$ 220$ and $\$ 600$ per ton, and even if the technology becomes more affordable, the problem of storage of the captured $\mathrm{CO}_{2}$ needs to be addressed.

In this connection, it is worth noting that carbon capture technologies (direct from air or from emitting sources), and carbon offset or removal mechanisms (reforestation, wetlands) could give rise to moral hazard. That is, as more carbon is taken out, the incentive to lower emissions might diminish. Many oil and gas companies are publicizing their research efforts and investments in carbon capture technologies, which leads one to believe that continued use of fossil fuels would be compensated by the capture of their associated emissions (Eberhart, 2021; Kuznets, 2020). Even the use of captured carbon to make cement, expanding wetlands to create offsets, and electrification of steel manufacture may not be entirely free of moral hazard, making it all the more imperative to evaluate the unintended consequences of technological solutions to the climate crisis.

In addition to the technological challenges to replacing coal, both China and India face serious social and political issues, some of which have been mentioned earlier, in making the transition.

\section{Social and Political Factors}

Though national policies on energy in both China and India are established by the central government and apply to the country as a whole, local needs and expectations may be prioritized even if they conflict with announced national directives. Consider the issue of employment in the energy sector. There is no doubt that reductions in the use of coal-fired energy may cause serious employment disruptions in both countries (Zhang, J., Liu, D., Xue, L.,Chen, X., and Wu, H., 2018). Employment in coal-related industries is close to 5 million in China, and nearly 4 million in India (Ibisworld, 2021; Mongabay, 2021)

Shanxi province in the north is the heart of coal country in China and accounts for about $20 \%$ of all coal-related employment. In the case of Shanxi, Shandung, and other regions whose stakeholders have a long history of energy from coal, the energy transition is not only about technological change. Displaced workers and the communities dependent on them need to be supported in some way. For older workers, paths to retirement might have to be worked out, while for younger workers, retraining programs for jobs of the future would be more appropriate. Reskilling schemes require care in designing and monitoring to ensure that they successfully place workers in appropriate openings or provide training in entrepreneurship (He, et. al, 2020)

The acceleration in growth of solar capacity in China has created over 2 million jobs in the sector (Jula, 2020) but these are very different types of jobs from those needed in the coal sector. It is also worth noting that coal is also used widely in rural areas for heating and cooking. The experience of Hebei province (in trying to switch from coal to gas rapidly) where many households were left without energy is an object lesson in the negative outcomes possible arising from a rapid transition (He, et. al., 2020).

There are other social issues, on the other hand, which necessitate an accelerated transition to clean energy. Foremost among these is the widespread expectation that pollution which has caused serious dislocations of life, and premature deaths of over one million will be tackled. There is considerable concern over air quality in particular due to the long term adverse health effects of rising temperatures, nitrous oxide, and particulate matter $\mathrm{PM}_{2.5}$ (Hong, et. al., 2019). Additionally, as China's population ages, the illnesses (pulmonary, cardiac, heat strokes, cognitive decline) attributable to warming and the increased presence of harmful gases could become even more extensive and dangerous. Clearly, there are internal forces in China pulling policy makers in opposite directions. They need to balance the immediate needs of stakeholders dependent on coal-based energies (mining communities, thermal power generators, industries such as cement and steel, and so on) against the long term impacts of climate change. Successfully addressing the latter offers the potential to be at the leading edge in installing, manufacturing, and advancing renewable energy technologies (solar, wind, batteries, hydrogen, etc.), and establish an "ecological 
civilization" (Goron, 2018) as promised by its leadership.

India faces challenges of its own in transitioning away from coal, some of which mirror problems faced by China, while others are specific to its context. The opposition of coal providers, users, and workers to sharply reducing use of the fuel is similar to that in China. The number of jobs affected is almost the same as China's. Coal is mined mostly in north-central and south-central India. Making the transition away from coal even more difficult in India is that over $30 \%$ of India's districts are dependent on some phase of the mine-to-user chain. It may be noted that three state-owned companies mine $80 \%$ of India's coal, earning revenues which are much needed by the government. Coal India (a state-owned enterprise), which is the largest coal company in the world, speaks with one voice and is seeking to expand (Jai, 2021; BBC, 2021). Renewable energy (RE) installations have, however, grown rapidly reaching a total of $100 \mathrm{GW}$ in 2021 , which constitutes about $25 \%$ of the country's electric power capacity, with bids out for another $75 \mathrm{GW}$. The country plans on installing a further $80 \mathrm{GW}$ by end 2022 , and 450GW by 2030 (Frangoul, 2021; Mint, 2021). Recently, India has attempted to build hybridized RE sources by amalgamating power from solar and wind to feed local or regional needs (Das, 2021). With solar and wind outputs peaking at different times of the day in the target areas, the power output from the hybridized REs is less jagged.

The speedy ramp up in RE capacity in India relative to coal power is partly attributable to the fact that REs have helped bring electricity to many villages which had hitherto lacked power supply. Another difference from China is that, while the policy to reduce carbon emissions was formulated by the central government, the implementation was undertaken at the state-level. These subnational efforts were focused on applications of most immediate concern to the states in question (Jorgensen, Mishra, and Sarangi, 2015). For instance, in some states, village electrification was prioritized, in others it was energy for irrigation, waste to energy, and so on. Also different from China has been the source of financing, the bulk of which has come from private funds. Typically, through the process of bidding on the price per kWh of electricity delivered, suitable companies have been entrusted with the building out of RE installations. This bottom up approach has minimized diversion of government funds while tailoring REs to local needs (Das, 2021; Wu, 2018).

Though the decentralized initiatives have helped increased the RE capacity, they also create a challenge. India's loose federal structure gives the states some latitude in following top-down directives, particularly when the political parties in power at the Central and State level are different. As in the case of China, this means that curtailing the use of coal in areas where it is most mined and/or used could prove tricky, even more so when such regions are critical to achieve or retain political power through elections. Political and social activism have also played a part in making the addition of nuclear capacity more uncertain, since local opposition could extend the duration and increase the cost of construction (Chandra, 2021).

Another challenge is that RE installation and operation creates far fewer jobs than does the coal sector. Solar energy installations are especially low in employment creation since their imported content is high. India's employment in solar is about one-fifth that of China's, per GW capacity (IRENA, 2018). Labor laws exacerbate the problem of employment in REs since employers find it difficult to reduce payroll when demand is down, making them reluctant to hire workers in the first place. Even when firms are interested in bidding for new wind or solar projects, they typically have to demonstrate that they will be able to obtain all the needed land and other local permissions prior to submitting their bids (Gupta, 2021). Local preferences and vested interests often trump national- and state-level mandates.

With a median age of a little over 25 , India faces a demographic problem which is, in a sense, the reverse of China's. The growing number of youth looking for jobs places immense pressure on governments at the state and central levels to provide them with employment opportunities. India's growing energy and employment needs could be met through REs if the equipment for the latter were produced, installed, and maintained with a welltrained, home-grown workforce.

The clustering of coal mines contributes to the economic and social stability of some regions in both countries. The dispersion of users results in a swathe of stakeholders resistant to the reduced use of coal. In the case of both countries, cutting back on the use of coal could potentially lead to economic hardship, social unrest, and even internal instability. China's emphasis on "common prosperity" and the unpredictable nature of India's electoral politics makes it unlikely that either country will act decisively to shift radically away from reliance of coal unless viable alternatives are at hand, and that the concerns of coal's stakeholders are satisfactorily addressed.

Both China and India have signaled that they view emission reduction as being subsumed within energy security (Wu, 2018). They have also worked with other countries to hold those most responsible for the original emissions accumulation assume greater responsibility in addressing climate change. However, partly to assuage the concerns of islands and small nations most threatened by warming, and also to tackle the impact of warming at home, China 
and India have committed to mitigation initiatives. China's standing, and India's desire to be seen, as a world power, have kept them at the negotiating table, but energy security, economic growth, and political stability remain their paramount concerns. It is worth noting that, at COP 26 held in Glasgow, neither country was willing to commit to eliminate coal from its energy mix. They were joined in the refusal to set a date for independence from coal by the United States, which means that the top three users of coal are, for reasons specific to each, locked into coal-for-energy for the next few decades.

\section{Conclusion}

Even if the EU and the US deliver on the pledge to be carbon neutral by 2050, in the absence of drastic measures to slash carbon emissions, in particular the use of coal, in China and India, net zero carbon could be well beyond reach even by mid-century. There are, however, some encouraging signs. While both countries see energy security as an overriding criterion, they have still acted to install REs on a large scale. For instance, India has set a target of achieving $500 \mathrm{GW}$ solar capacity by 2030 , which is equivalent to its total present electricity output. The country is also ramping up its manufacturing capabilities in solar panel through domestic firms as well as with financing from the U.S. (WSJ, 2021; Gupta, 2021). Mechanisms and technologies to more fully utilize power from RE sources (e.g. the use of AI to manage intermittency on smart grids; enhance power storage capacity and duration) could facilitate a gradual shift away from coal. Other actions such as reskilling of the workforce, compensating industries most affected by the transition, easing labor regulations, and finding carbon-substitution methods customized to their needs are among the initiatives which are worth considering. India's nuclear plans are ambitious, but progress has been slow in adding new capacity. With about $7 \mathrm{GW}$ of installed capacity and 8GW planned to be added, India has, till recently put nuclear power on the back burner. However, plans are in place to increase nuclear's role in the energy mix. An instance is the agreement concluded in April 2021 between EDF and NPCIL on the construction of 6 EPR reactors, accompanied by a financial support and technology transfer package (The Hindu Businessline, 2021). China, on the other hand, plans on adding $180 \mathrm{GW}$ of nuclear capacity by 2035 , thus reducing its dependence on coal slightly (Murtaugh and Chia, 2021).

China's investments in hydrogen production and its related value chain are rising sharply, with support from the central government and major cities. Green hydrogen, generated by using renewables to electrolyze water, is targeted for use as a storage mechanism as well as to be used in vehicles (He, 2021). The country's recent pledge to be carbon neutral by 2060 is, in part, based on its ambitious nuclear and hydrogen targets. India's recently launched National Hydrogen Mission has a similar intent directed toward producing hydrogen from its rapidly growing renewable capacity. Domestic firms are already engaged in researching and producing hydrogen at scale (CNBC, 2021). It needs to be kept in mind that hydrogen technology, both its production and logistics, is far from being commercially viable. However, with both developed and developing nations focused on this technology, its potential is massive for reducing carbon emissions in the next ten years.

It is also imperative that both Asian nations (and other coal-dependent countries) be provided technological, economic, and other forms of assistance to facilitate their achievement of net zero carbon as committed. The $\$ 8.5$ billion deal struck at COP 26 to facilitate South Africa slashing its reliance on coal might serve as a model for targeted financing (BBC, 2021). Rich nations have delivered a miniscule portion of the $\$ 100$ billion per year promised in the Paris Agreement to developing countries. The total amount transferred in 2018 (Shankleman, 2020) mostly in the form of loans, translated to a net disbursement of $\$ 30$ billion. The U.S. commitment of around $\$ 10$ billion is well short of its original commitment (McDonnell, 2021). Foreign aid as compensation for the stock of emissions is unpopular in most developing nations. The funds needed by developing nations could exceed $\$ 500$ billion per year by 2050 (Ljunggren, 2021). Indian authorities have signaled that their needs alone amount to over two trillion dollars over the next ten years for them to wean the economy off coal (Carbonbrief, 2019). It is possible the U.S. will collaborate in the endeavor with India (Busby, et. al., 2021). The EU is also working with India to support its efforts both in terms of financial resources as well as new technologies. Post-COP 26, Brussels and Delhi have pledged to cooperate more closely on climate issues, holding out the likelihood, among other initiatives, of a joint green hydrogen project (Brzozowski, 2021). The China-U.S. agreement to collaborate on climate was one of the high points of COP 26 , and holds out the promise of potentially significant joint action in the years to come (Plumer and Friedman, 2021).

The Carbon Border Adjustment Mechanism (CBAM) proposed by the European Commission could also provide an incentive for countries doing business with the EU to cut down on emissions. The CBAM covers a selection of carbon-intensive basic materials relating to steel, cement, fertilisers, aluminium and electricity generation, as well as a handful of items down the value chain, such as steel pipes, containers, railway materials. They represented EUR 6.5bn of exports from China to the EU27 in 2019. Other carbon-intensive basic materials targeted by the EU though not by the current CBAM proposal include glass, ceramics, pulp and paper. (Assous, Burns, Tsang, 
Vangenechten, Schape, 2021). The direct impact on the EU's imports from China does not seem critical with imports of EUR 6.5 bn being affected, with potential to impact a further EUR $11.5 \mathrm{bn}$. The CBAM has the potential to change the rules of global competitiveness and affect not only China, India, but also Russia, and a majority of developing countries lacking an emission certificate system and with a carbon-based energy mix. But on the other hand it will constitute a strong incentive for them to change climate policies and NDCs.

It may be noted that China, which may account for over a third of emissions by 2035 , is in a different category from India. Since it is viewed as a rival to the EU, Japan, and the US in a range of technologies (biotech, information, communications, EVs, AI, aerospace, and others), helping China make good on its GHG commitments could clash with efforts to limit its rise as an economic, technological, and military powerhouse. Dealing with this paradox would require a delicate balancing act between competition and cooperation. Policy tools, like the EU's Fit for 55 (Europe, 2021(a)) and CBAM (Europa, 2021(b)), will probably have an impact on China's export competitiveness, and China's policy response is difficult to predict. It is critical for all parties (countries and institutions) concerned, to separate the issue of global leadership from that of ensuring the wellbeing of the planet as a whole.

It is unquestionable that energy security is integral to national security, particularly in the case of world and regional powers. Where China and India are concerned, coal has been and remains central to energy security. However, both countries are expanding the search for alternative sources of energy, in part to benefit their own populations and also to comply with an emerging global consensus on mitigating carbon emissions. Numerous hurdles remain, such as the commercialization and transfer of substitute technologies, financing their implementation, overcoming the social and political problems arising from the transition away from coal, and so on. However, it appears that both China and India have embarked on a process of lowering their dependence on coal for energy over the next few decades. The speed at which this transition plays itself out remains to be seen.

\section{References}

Assous A., Burns T., Tsang B., Vangenechten D., \& Schape B. (2021). A Storm in a Teacups Impacts and Geopolitical Risks of the European Carbon Border Adjustment Mechanism, Sandbag Report. Retrieved from https://www.efchina.org/Attachments/Report/report-po-20210913/E3G-Sandbag-CBAM-Paper-Eng.pdf

BBC. (2021). https://www.bbc.com/news/business-56506529

Birks, M., \& Mills, J. (2015). Grounded Theory: A Practical Guide. London: Sage.

Brookings. (2019). https://www.brookings.edu/research/coal-in-india/

Brookings. (2021). https://www.brookings.edu/blog/planetpolicy/2021/10/25/net-zero-carbon-pledges-havegood-intentions-but-they-are-not-enough/

Brzozowski, A. (2021). https://www.euractiv.com/section/eu-india/news/eu-india-eye-deeper-cooperation-onsolar-green-hydrogen/

Busby, J., Shidore, S., Urpelainen, D., \& Bazilian, M. (2021). https://www.brookings.edu/research/the-case-forus-cooperation-with-india-on-a-just-transition-away-from-coal/

Carbon Tracker. (2021). https://carbontracker.org/paris-target-at-risk-as-five-countries-plan-80-of-worlds-newcoal-power/

Carbonbrief. (2019). https://www.carbonbrief.org/the-carbon-brief-profile-india

Chandra, V. (2021). https://ari.nus.edu.sg/ariscope/social-opposition-to-nuclear-power-plants-in-india-assessingtheir-impact-on-state-policy

Chatsko, M. (2018). China's Renewable Energy growth isn't as good as it seems. Retrieved from https://www.fool.com/investing/2018/06/04/chinas-renewable-energy-growth-isnt-as-good-as-it.aspx

Clancy, H. (2021). https://info.greenbiz.com/index.php/email/emailWebview?md_id=24067

Climate Action Tracker. (2018). https://climateactiontracker.org/publications/warming-projections-global-updatedec-2018/

Climate Action Tracker. (2020). https://climateactiontracker.org/countries/india/pledges-and-targets/

Climate Action Tracker. (2021a). https://climateactiontracker.org/countries/china/

Climate Action Tracker. (2021b). https://climateactiontracker.org/countries/india/

CNBC. (2021). https://www.cnbc.com/2021/03/10/india-turns-to-green-hydrogen-in-a-bid-to-decarbonize-itseconomy.html 
Darby, M., \& Gerretsen, I. (2019). Which countries have a Net Zero Carbon Goal? Retrieved from https://www.climatechangenews.com/2019/06/14/countries-net-zero-climate-goal/

Das, B. (2021). https://www.downtoearth.org.in/blog/energy/renewable-energy-integration-in-india-ways-tomaximise-solar-wind-power-system-78391

Eberhart, S. (2020). https://www.forbes.com/sites/daneberhart/2021/03/09/oil-giants-bet-big-on-expected-2trillion-carbon-capture-market/?sh=1a5ec1c3e8a 4

Edens, R. (2018). https://www.scmp.com/comment/insight-opinion/article/2138327/india-crafts-its-own-stringpearls-rival-chinas-naval-jewels

EIA. (2018). EIA's latest International Energy Outlook highlights analysis of China, India, and Africa. Retrieved from https://www.eia.gov/todayinenergy/detail.php?id=36732

EIA. (2018). https://www.eia.gov/todayinenergy/detail.php?id=36732

EIA. (2019). https://www.eia.gov/ieo

EIA. (2020). https://www.eia.gov/todayinenergy/detail.php?id=43655

Energy. (2021). How we are moving to net zero carbon by 2050. April 19. Retrieved from https://www.energy.gov/articles/how-were-moving-net-zero-2050

Europa. (2020). Committing to carbon neutrality by 2050, Mar. 4. Retrieved from https://ec.europa.eu/commission/presscorner/detail/en/ip_20_335

Europa. (2021a). https://ec.europa.eu/commission/presscorner/detail/en/IP_21_3541

Europa. (2021b). https://ec.europa.eu/taxation_customs/green-taxation-0/carbon-border-adjustmentmechanism_en

Forbes. (2021). https://www.forbes.com/sites/judeclemente/2019/10/17/china-is-the-worlds-largest-oil--gasimporter/?sh=7ec0e9e15441

Frangoul, A. (2021). https://www.livemint.com/industry/energy/indias-installed-renewable-energy-capacitycrosses-100-gw-11628781563745.html

Garside, M. (2021). https://www.statista.com/statistics/265510/countries-with-the-largest-coal-consumption/

Glaser, B. (1992). Basics of Grounded Theory Analysis. Mills Valley, CA: Sociology Press.

Goron, C. (2018). Ecological Civilization and the Political Limits of a Chinese Concept of Sustainability. China Perspectives, 4, 39-52. https://doi.org/10.4000/chinaperspectives.8463

Gupta, U. (2021). https://www.pv-magazine-india.com/2021/04/10/the-long-read-the-feasibility-of-indiasauctions/

Hari, V. (2019). https://asia.nikkei.com/Opinion/New-alliances-not-a-silver-bullet-for-energy-security-in-Chinaand-India Oct. 2

He, G., Lin, J., Zhang, Y., Zhang, W., Larangeira, G., Zhang, C., Peng, W., Liu, M., \& Yang, F. (2020). https://www.ncbi.nlm.nih.gov/pmc/articles/PMC7442150/

He, H. (2021). https://www.wsj.com/articles/india-seeks-its-own-solar-industry-to-counter-china-11639573204

Hoffmann, J. (1995). Implicit Theories in Policy Discourse: An Inquiry into the Interpretations of Reality in German Technology Policy. Policy Sciences, 28, 127-48. https://doi.org/10.1007/BF00999672

Hong, Q. et. al. (2019). Impacts of Climate Change and Air Quality on future health in China. https://doi.org/10.1073/pnas.1812881116

Hong, Z. (2012). China and India: The quest for energy resources in the twenty-first century. London: Routledge.

Hughes, L. (2019). String of Pearls redux: China, India, and a Cambodian base. Retrieved from https://www.futuredirections.org.au/publication/string-of-pearls-redux-china-india-and-a-cambodian-base/

Ibisworld. (2021). https://www.ibisworld.com/china/market-research-reports/coal-mining-industry/

IEA. (2020). https://www.iea.org/reports/coal-2020/demand

IEA. (2021). https://www.iea.org/reports/india-energy-outlook-2021

IEEFA. (2022). https://ieefa.org/ieefa-india-developed-countries-will-have-to-massively-scale-up-climatefinance/ 
IPCC. (2021). https://www.ipcc.ch/report/ar6/wg1/downloads/report/IPCC_AR6_WGI_SPM.pdf

IRENA. (2018). Renewable Energy and Jobs: Annual Review 2018. Retrieved from https://irena.org//media/files/irena/agency/publication/2018/may/irena_re_jobs_annual_review_2018.pdf

Jai， S. (2021). https://www.business-standard.com/article/companies/coal-india-approves-32-mining-projectsworth-rs-47-000-cr-this-fiscal-121030800826_1.html

Jörgensen, K., Mishra, A., \& Sarangi, G. (2015) Multi-level climate governance in India: the role of the states in climate action planning and renewable energies. Journal of Integrative Environmental Sciences, 12(4), 267283. https://doi.org/10.1080/1943815X.2015.1093507

Jula, M. (2020). https://www.motherjones.com/environment/2018/05/report-china-now-has-9-times-as-manysolar-jobs-as-the-us/

Kramarz. T.. Park. S.. \& Johnson. C. (2020). Governing the dark side of renewable energy: A typology of global displacements. Energy Research \& Social Science, 74, 101902. https://doi.org/10.1016/j.erss.2020.101902

Kuznets, N. (2020). https://insideclimatenews.org/news/27092020/exxon-carbon-capture/

Lebling, K., McQueen, N., Pisciotta, M., \& Wilcox, J. (2021). https://www.wri.org/insights/direct-air-captureresource-considerations-and-costs-carbon-removal

Ljunggren, D. (2021). https://www.reuters.com/business/cop/developed-nations-say-they-can-deliver-100-blnclimate-change-fund-by-2023-three-2021-10-25/

Lu, T., Sherman, P., Chen, X., Chen, S., Lu, X., \&McElroy, M. (2020). India's potential for integrating solar and on- and offshore wind power into its energy system. Retrieved from https://www.nature.com/articles/s41467020-18318-7

McDonnell, T. (2021). https://qz.com/2000418/rich-countries-need-to-cut-the-strings-off-climate-finance/

Mint. (2021). https://www.livemint.com/industry/energy/indias-installed-renewable-energy-capacity-crosses100-gw-11628781563745.html

Mohan, A., \& Wehnert, T. (2019). Is India pulling its weight? India's nationally determined contribution and future energy plans in global climate policy. Climate Policy, 19(3), 275-28. https://doi.org/10.1080/14693062.2018.1503154

Mongabay. (2021). https://india.mongabay.com/2021/07/about-40-percent-of-indias-districts-have-some-form-ofcoal-dependency/

Morningstar, R. (2020). https://www.atlanticcouncil.org/in-depth-research-reports/issue-brief/european-energydiversification-how-alternative-sources-and-routes-can-bolster-energy-security-and-decarbonization/

Murtaugh D., \& Chia, K. (2021). China's Climate Goals Hinge on a $\$ 440$ Billion Nuclear Buildout. Retrieved from https://www.bloomberg.com/news/features/2021-11-02/china-climate-goals-hinge-on-440-billion-nuclear-powerplan-to-rival-u-s

Myllyvirta, L. (2021). https://www.carbonbrief.org/analysis-chinas-carbon-emissions-grow-at-fastest-rate-formore-than-a-decade

NASA. (2020). Climate Change: How do we know? Retrieved from https://www.climate.nasa.gov/evidence/

Nature. (2020). https://www.nature.com/articles/s41467-020-18318-7

OECD. (2015). The Carbon Foot- print of International Trade. Retrieved from https://www.itfoecd.org/sites/default/files/docs/cop-pdf-06.pdf

Physics World. (2018). https://physicsworld.com/a/why-arent-chinas-wind-farms-producing-more-electricity/

Plumer, B. (2017, April 18). A closer look at how rich countries "outsource" their $\mathrm{CO}_{2}$ emissions to poorer ones. Vox. Retrieved from https://www.vox.com/energy-and-environment/2017/4/18/15331040/emissionsoutsourcing-carbon-leakage

Plumer, B., \& Friedman, L. (2021). https://www.nytimes.com/2021/11/10/climate/climate-cop26-glasgow.html

Reuters. (2021). https://www.reuters.com/business/cop/india-says-consensus-over-cop26-climate-deal-remainselusive-2021-11-13/

Richie, H. (2019). https://ourworldindata.org/contributed-most-global-co2

Richie, R., \& Roser, M. (2019). https://ourworldindata.org/co2/country/india\#per-capita-how-much-co2-does-the- 
average-person-emit

Roberts, D. (2020). https://www.vox.com/energy-and-environment/2020/3/14/21177941/climate-change-coalrenewable-energy

Russell, C. (2019). https://www.reuters.com/article/column-russell-coal-iea/column-china-india-are-both-theproblem-and-solution-for-coal-climate-change-russell-idUSL4N27U10R

Shankleman, J. (2020). https://www.bloomberg.com/news/articles/2020-11-06/rich-countries-are-missing-the100-billion-climate-finance-goal

Sovacool, B. (2021). Who are the victims of low-carbon transitions? Towards a political ecology of climate change transition, 73, pp.1-16. https://doi.org/10.1016/j.erss.2021.101916

Standaert, M. (2021, April 5). Despite pledge to reduce emissions, China is bingeing on coal. Retrieved from https://www.motherjones.com/environment/2021/04/despiteemissions-pledges-china-is-bingeing-on-coal/

Standway, D. (2021). https://www.reuters.com/article/us-china-coal/chinas-new-coal-power-plant-capacity-in2020-more-than-three-times-rest-of-worlds-study-idUSKBN2A308U

Statista. (2021). https://www.statista.com/statistics/270499/co2-emissions-in-selected-countries/

Steiner, R. (2021). https://www.newgeography.com/content/006560-china-and-india-rejecting-renewables-coalfired-futures

Temple, R. (2019). https://www.technologyreview.com/2019/10/10/369/how-a-new-class-of-startups-areworking-to-solve-the-grid-storage-puzzle/

The Hindu Businessline. (2021). https://www.thehindubusinessline.com/companies/frances-edf-offers-knowhowgear-for-jaitapur-nuclear-plant/article34395661.ece

Timperley, J. (2019). https://www.carbonbrief.org/the-carbon-brief-profile-india

UNEP. (2021). www.unep.org/resources/emissions-gap-report-2019

Vaidyanathan, R. (2021). Climate change: Why India can't live without coal. Retrieved from https://www.bbc.com/news/world-asia-india-58706229

Varadhan, S., \& Sheldrick, A. (2021). COP 26 needs to banish coal, Asia is building hundreds of power plants to burn it. Retrieved from https://science.thewire.in/author/svaradhan-asheldrick/

Wallace-Wells, D. (2019). The Uninhabitable Earth: Life After Warming. New York: Time Duggan Books.

Wang, Q., \& Zhou, Y. (2020). Evolution and Drivers of production-based carbon emissions in China and India: Differences and Similarities. Journal of Cleaner Production, 277, 1-16. https://doi.org/10.1016/j.jclepro.2020.123958

WEF. (2021). https://www.weforum.org/agenda/2021/01/coal-demand-asia-decarbonize-emissions/

World Population Review. (2021). https://worldpopulationreview.com/country-rankings/carbon-footprint-bycountry

Worldoil. (2020). https://www.worldoil.com/news/2020/12/7/china-india-show-new-interest-in-oil-from-ussanctioned-nations

WSJ. (2021). https://www.wsj.com/articles/india-seeks-its-own-solar-industry-to-counter-china-11639573204

Xu, M., \& Stanway, D. (2021). China doubles Renewable Capacity in 2020; still builds Thermal Plants. Retrieved from https://www.reuters.com/article/us-china-energy-climatechange/china-doubles-new-renewablecapacity-in-2020-still-builds-thermal-plants-idUSKBN29Q0JT

Yergin, D. (2020). The New Map: Energy, Climate, and the Clash of Nations. New York: Penguin.

Yin, B. (2021). https://thediplomat.com/2021/12/india-and-china-can-quit-coal-earlier-but-the-world-must-workalongside-them/

Zhang, J., Liu, D., Xue, L., Chen, X., \& Wu, H. (2018). Achieving a Socially just energy transition in China. Retrieved from http://library.fes.de/pdf-files/bueros/china/14552.pdf 


\section{Copyrights}

Copyright for this article is retained by the author(s), with first publication rights granted to the journal.

This is an open-access article distributed under the terms and conditions of the Creative Commons Attribution license (http://creativecommons.org/licenses/by/4.0/). 